\title{
Aging and sexual activity: gynecological, sexological and psychological aspects
}

\section{Starzenie się i aktywność seksualna - aspekty ginekologiczne, seksuologiczne i psychologiczne}

\author{
Grażyna Jarząbek-Bielecka1, Elżbieta Sowińska-Przepiera ${ }^{1,2}$, Michał Pawlaczyk ${ }^{1}$ \\ ${ }^{1}$ Division of Developmental Gynecology and Sexology of the Department of Perinatology and Gynecology, \\ Poznań University of Medical Sciences; \\ Head of Department: dr hab. n. med. Grażyna Jarząbek-Bielecka \\ ${ }^{2}$ Department of Endocrinology, Metabolic Diseases and Internal Diseases, Pomeranian Medical University, Szczecin, Poland; \\ Head of Department: prof. dr hab. n. med. Anhelli Syrenicz
}

Przegląd Menopauzalny 2012; 6: 487-489

\section{Summary}

Aging brings about a number of physical and psychological changes that can have an impact on sexual performance and pleasure. Sexual activity is a natural and important part of a healthy lifestyle, no matter what women's or men's age is. Although the amount of sexual activity generally declines with age, sexual interest and ability can remain fairly constant. While the need for and interest in sex vary widely in people, most people experience sexual desire throughout life. A diversity of complex controlling factors as well as an abundance of ways in which human sexuality is expressed remains an important methodological problem which impedes a scientific description of the phenomenon in question. In modern society many aspects of lifestyle, including physical activity, love, sex, fashion, learning and others have crossed the border set in the past. More attention needs to be paid to sexual problems of our aging patients.

Key words: women, sexology, gynecology, aging.

\section{Streszczenie}

Przekwitanie stanowi okres przejściowy w życiu człowieka między okresem reprodukcyjnym a okresem starzenia się. Zazwyczaj starsi ludzie rzadko wypowiadają się na temat swojego życia seksualnego, nawet pytani o tę sferę przez lekarzy. Są jednak osoby w okresie przekwitania, które w swojej ocenie są atrakcyjne seksualnie, będące zdania, że doświadczanie uczucia i zmysłowej przyjemności to cenna część starszego wieku. Zagadnienia te są bardzo istotne zarówno w aspekcie seksuologii, jak i ginekologii.

Słowa kluczowe: kobieta, seksuologia, ginekologia, przekwitanie.

Sex and aging are topics most older women do not want to talk about. The most obvious changes in a woman's body as she ages come with climacterium. During climacterium, decreasing estrogen levels cause physical changes that may impact the sexual function. Aging may also bring emotions that can interfere with sex [1, 2]. While estrogen production decreases it alters the thickness and size of a woman's reproductive organs. These changes include:

- loss of elasticity and thinning of the vaginal tissue,

- decrease in the amount of lubrication,

- decrease in the size of the clitoral, vulvar and labial tissues,

- decrease in the size of the cervix, uterus and ovaries.
These changes alter the experience of sex in the following ways:

- the anticipation before orgasm decreases,

- orgasms may be less intense,

- sexual desire may be reduced,

- however, the sensitivity of the clitoris remains the same. For women, vaginal discomfort, dryness or pain during intercourse may occur, due to decreased lubrication, as a result of hormonal changes related to climacterium. Treatment and ways to adapt are available. Sensitivity to breast stimulation may also occur. Men may notice that achieving an erection may take longer and that it may not be as large or firm as before. Orgasms may be less 
intense than in their youth. These changes are normal and a result of a decrease in hormones. Again, treatment and ways to adapt are available. While the normal changes of aging can affect sexual response and desire, other factors can also increase the challenge. They include:

- smoking,

- excess alcohol (more than two drinks a day),

- obesity,

- lack of self-confidence,

- depression,

- performance anxiety.

Lack of sexual desire beyond the normal changes of aging can sometimes be related to an underlying health problem. Diabetes, high blood pressure and prostate problems can affect sexual desire and performance. Heart disease, osteoporosis, arthritis, incontinence and emphysema can also affect physical ability and enjoyment of sexual activity. Prescription drugs to treat conditions such as depression and high blood pressure can suppress desire and performance.

Aging and the cessation of ovarian function accompanying menopause can significantly affect the sexualresponse cycle of women. Sexual desire and frequency of intercourse decrease as women age, although women remain interested in sex and continue to have the potential for sexual pleasure for their entire lives. The need for closeness, love, and intimacy does not change with advancing age. The way women function sexually as they grow older is largely dependent on partner availability and how frequently they had sex and how much they enjoyed sex when they were younger [2, 3].

Anatomic and physiologic changes that accompany aging in women include reduced vaginal size, thinning and decreased elasticity of the vaginal walls, a change in the vaginal $\mathrm{pH}$ from acidic to alkaline, shrinkage of the labia majora and thinning of the labia minora, decreased clitoral sensitivity and size, reduced perineal muscle tone, possible uterine or bladder prolapse, and a thinner orgasmic platform. Breast atrophy, decreased breast engorgement during arousal, and sensory changes in the nipple and areola are also noted. These anatomic changes predispose women to more frequent episodes of vulvovaginitis and urinary tract infections, which, along with decreased vaginal lubrication, may cause dyspareunia.

As they age, women require more time to become sexually aroused, take longer to lubricate, produce less vaginal lubrication, have less intense orgasms, and need more clitoral stimulation to become orgasmic. The ability to have orgasms does not change significantly with aging, but older women are less likely to be multiorgasmic. Women who are coitally active after menopause have less vulvar and vaginal atrophy and higher titers of androgen than abstinent women $[3,4]$.

A diversity of complex controlling factors as well as an abundance of ways in which human sexuality is expressed remains an important methodological problem which impedes a scientific description of the phenomenon in question.

Sexual activity is a natural and important part of a healthy lifestyle, no matter what one's age is. Although the amount of sexual activity generally declines with age, sexual interest and ability can remain fairly constant. While the need for and interest in sex vary widely in people, most people experience sexual desire throughout life. Maintaining a level of sexual activity makes the biological changes associated with aging less pronounced, with less impact on overall sexuality. Many older couples say that they enjoy sex more now than when they were younger. They have more privacy, life has fewer stresses and for heterosexual couples, the risk of unwanted pregnancies disappears.

Aging brings about a number of physical and psychological changes that can have an impact on sexual performance and pleasure. An important predictor of how active sex life people will have in later years is their overall physical health $[4,5]$.

There are many benefits in maintaining a healthy sexual activity level in later years:

- Sex burns fat and causes the brain to release endorphins, natural chemicals that act as painkillers and reduce anxiety.

- In men, sex stimulates the release of growth hormones and testosterone, which strengthen bones and muscles.

- Sex also seems to prompt the release of substances that bolster the immune system.

- Some studies suggest that sex (performed about three times a week) can slow aging and prevent wrinkles around the eyes from appearing.

- The physical exertion associated with sex is about the same as walking up two flights of stairs. If your heart is up to that much exercise, it is probably up to sex.

- Continuing to have sex will preserve your sexual vigor beyond middle age. Sexually active people have higher levels of naturally produced sex hormones.

Men also experience physiologic changes and a decrease in sexual desire and frequency as they age. There is a decrease in the number of nocturnal and morning erections. Men may require more intense penile stimulation for arousal (erection) and ejaculation. Erections tend to be less rigid, sometimes making intercourse difficult. Penile detumescence is more rapid, and the refractory phase is much longer in the older male [6].

Management of sexual difficulties in older women should include local or systemic estrogen supplementation to alleviate vaginal dryness, urinary tract symptoms, and dyspareunia. Other suggestions might include taking a warm bath before lovemaking to loosen stiff joints, making love in the morning when the couple is less fatigued, and experimenting with sexual stimulation to orgasm without having intercourse. 


\section{Medical problems}

Both acute illness (myocardial infarction) and chronic illness (renal disease or arthritis) can create depression, a distorted body image, and physical discomfort and can disturb the hormonal, vascular, and neurologic integrity needed for sexual functioning. Neurologic disorders that impair sexual functioning include multiple sclerosis, alcoholic neuropathy, and spinal cord injury. Endocrine and metabolic disorders such as diabetes mellitus, hyperprolactinemia, testosterone deficiency, estrogen deficiency, and hypothyroidism can affect sexual response $[6,7]$.

A variety of prescription and nonprescription medications and illicit drugs can alter the sexual response in men and women. These include antihypertensives, thiazide diuretics, antidepressants (especially the serotonin reuptake inhibitors), antipsychotics, antihistamines, barbiturates, narcotics, benzodiazepines, oral contraceptives, and recreational drugs like cocaine and marijuana.

The sexual dysfunctions include sexual desire disorders (e.g. hypoactive or inhibited sexual desire and sexual aversion), sexual arousal disorders, orgasmic disorders, sexual pain disorders (e.g. vaginismus and dyspareunia), and sexual disorders due to general medical conditions and substance abuse. Each disorder can be further classified as lifelong or acquired (i.e., after a period of normal sexual functioning), generalized (i.e., not limited to a specific partner or situation), or situational.

Obstetrician-gynecologists may be called upon to counsel women about their male partner's sexual health. Therefore, they should be familiar with the male sexualresponse cycle and the common causes and treatment of sexual dysfunction in men. Erectile dysfunction is the inability to develop an erection or to maintain a rigid erection long enough for completion of intercourse. The term erectile dysfunction is preferable to impotence. Erectile dysfunction is common and is age-dependent, increasing as men age. The prevalence of erectile dysfunction in men aged $40-70$ years is about $50 \%$. Similar to the female sexual dysfunctions, erectile dysfunction can be lifelong or acquired, generalized or situational. The other male sexual dysfunctions commonly encountered (i.e., hypoactive sexual desire, delayed or absent orgasm, and premature ejaculation) can contribute to the development of erectile dysfunction.
Erectile dysfunction that occurs suddenly and intermittently is often associated with psychological causes such as depression and anxiety, whereas erectile dysfunction that is gradual, persistent, and progressive is usually organic in etiology. Most men with erectile dysfunction are now thought to have an organic cause for their condition, especially circulatory insufficiency, with psychological issues as important contributing factors. Common causes of erectile dysfunction include surgery (prostatectomy), aging, cigarette smoking, and chronic medical conditions such as multiple sclerosis, diabetes mellitus, hypertension, atherosclerosis, and heart disease.

Erectile dysfunction is also associated with medications like antihypertensives (especially thiazide diuretics) and psychotropics [7, 8]. The use of recreational drugs and alcohol also contributes to erectile dysfunction. Endocrine causes of erectile dysfunction include bilateral testicular atrophy, hypothyroidism, and prolactinomas.

Many young, sexually active people do not experience the whole range of sensations that love between two elderly people gives. Luckily, the ability to share feelings, show affection and love does is not determined by the amount of muscles we have or perfect body fitness. This ability does not shrink with age.

\section{References}

1. Masters WH, Johnson V. Human sexual response. Little, Brown and Company, Boston 1966.

2. Basson R. Female sexual response: the role of drugs in the management of sexual dysfunction. Obstet Gynecol 2001; 98: 350-3.

3. Steers WD, Neural pathways and central sites involved in penile erection: neuroanatomy and clinical implications. Neurosci Biobehav Rev 2000; 24: 507-16.

4. Park K, Kang HK, Seo JJ, et al. Blood-oxygenation-level-dependent functional magnetic resonance imaging for evaluating cerebral regions of female sexual arousal response. Urology 2001; 57: 1189-94.

5. Gizewski ER, Krause E, Karama S, et al. There are differences in cerebral activation between females in distinct menstrual phases during viewing of erotic stimuli: A fMRI study. Exp Brain Res 2006; 174: 101-8.

6. Krüger TH, Hartmann U, Schedlowski M. Prolactinergic and dopaminergic mechanisms underlying sexual arousal and orgasm in humans. World J Urol 2005; 23: 130-8.

7. Nass G, Libby R, Fisher M. Sexual choices. Jones and Bartlett Publishers, Boston 1987.

8. http://www.healthycanadians.gc.ca/health-sante/sexual-sexuelle/senior-aine-eng.php 